\title{
The Search for Smith Wildman Brookhart: A Pilgrim's Progress
}

\author{
GEORGEWILLIAM MCDAN I E L
}

I have always known about Senator Smith Wildman Brookhart: we share Washington, Iowa, as a home town, and the Brookhart law office and home became familiar landmarks to me as I grew up. I also remember a youthful hometown pride that one of our own had moved on to Washington, D.C., to serve in the United States Senate. But I was only two years old when he died, so I did not actually know him.

It was not until I was in graduate school at The University of Iowa, however, that I began to know Smith Brookhart. Enrolled in Professor Ellis Hawley's seminar in 1976, I needed a topic for my seminar paper. I still knew only the bare outlines of the Brookhart story. A Washington County Attorney and progressive Republican party leader in Iowa, Brookhart had been elected to the United States Senate in 1922 and had served until he was defeated in the primary of 1932 . But a footnote in the Iowa Official Register caught my eye. In the election of 1924 Brookhart had run against the Democrat Dan Steck, had apparently won the election, but the election "was contested . . . and on April 12, 1926, the U.S. Senate voted . . to unseat" Brookhart. It added that he went on to win election in the fall campaign.

I wondered why he had been thrown out of the Senate and thought that perhaps that story would make a good seminar paper. The seminar paper later became my master's essay and, still later, a part of my Ph.D. dissertation. With revisions and some additional material, I am now writing a complete biography of Brookhart. When I began the seminar paper, however, I had no notion that twelve years later I would still be writing about Smith Brookhart. I now feel an affinity with John Bunyan who wrote at the beginning of The Pilgrim's Progress that:

When at the first I took my pen in hand, Thus for to write, I did not understand That I at all should make a little book In such a mode. 
Like Bunyan's Pilgrim, I set out as an innocent on a walk "through the wilderness of this world" in search of Smith Wildman Brookhart.

I soon discovered that other pilgrims had preceded me into the wilderness. A 1932 study had analyzed the elections of Brookhart. There was an honors thesis at Columbia, some master's theses, and a few articles in journals. One of my predecessors, Ray S. Johnston, had written a master's thesis under the direction of Professor Leland Sage at the University of Northern Iowa. A self-confessed "Brookhart junky," Ray Johnston has maintained an interest in my pilgrimage and has supported me at every step.

The most important guides, however, were members of the senator's family. Shortly after I chose my original seminar topic, I wrote his daughter Florence Brookhart Yount, a retired physician living in Prescott, Arizona. Florence had grown up in Washington, Iowa, and knew my family, so my name was familiar to her. I asked whether I could have access to her father's papers.

Dr. Yount told me that most of her father's papers had been destroyed shortly after his death in 1944. She said, however, that she had some clipping scrapbooks and a few other things that I was welcome to use. She also referred me to her brother, Smith Brookhart, Jr., a retired attorney living in Denver, Colorado, and to her sister, Edith Brookhart Millard, who lived in Chevy Chase, Maryland.

In the years since, the Brookhart children have shared their memories of their father and have opened their homes to me. I have made three trips to the Yount home in Arizona and have also visited Smith Brookhart, Jr. in Denver and Mrs. Millard in her home in Maryland. Moreover, they have never failed to respond to the many questions I have asked them by letter. They have also paid me a high compliment by admitting that my research has told them things about their father they did not know. Dr. Yount and Mrs. Millard have since died, and it is a source of sadness for me that they did not live to see the completion of the project. 
Still, the memories of the family could only supply part of what I needed to know. Without the senator's papers, the public part of his life had to be re-created from other sources. I began with the Congressional Record, which, fortunately, has a good index. I knew that it is not always a reliable record, since senators are allowed to edit their speeches after delivering them. Nevertheless, it gave me a good sense of what Brookhart thought was important, and I found that very often a speech would contain a great deal of personal information. In the course of ten years of speeches in the Senate, for example, Brookhart provided nearly all the essentials concerning his military career.

As a complement to the Congressional Record, I also read the transcripts of Congressional hearings. Again an index helped me to locate not only the records of the committees on which Brookhart served but also committees before which he gave testimony-before, during, and after his years as a senator. It helped to have these government sources close at hand, in the Government Publications Department of the University Libraries. The librarians there were masterful guides, leading me through the arcane wilderness of government publications. They saved me many hours of work and kept me from countless false paths.

The senator's voting record was a third valuable source for official congressional activities. Here computer technology proved to be a valuable asset. The Inter-university Consortium for Political and Social Research, in Ann Arbor, Michigan, provided a printout which listed every recorded vote during Brookhart's years in the Senate. The data included how he voted on the issues as well as the vote margin. These three congressional sources became the basis of my information on the public career of Brookhart.

I also studied the public record as contained in newspapers. I began with the New York Times, principally because it was indexed. The most helpful newspaper source, however, was the Des Moines Register. I did most of this phase of the newspaper work in the Microtext Reading Room of the Main 
Library, where a friendly and competent staff made the journey easier. I eventually read most of the issues of the Register for the years 1922-1936. In addition to news stories, the Register published letters to the editor and it also extracted editorial opinion from many Iowa newspapers. This gave me a sense of the issues and also told me a great deal about what Iowans were thinking.

The Register also helped me to follow Brookhart around the state on his many campaign trips. I prepared an itinerary based on the Register's news stories and then consulted the newspaper in each town he visited. I could usually find the newspapers in the State Historical Society of Iowa library in either Des Moines or Iowa City. Occasionally I would travel to a nearby city or request the papers on microfilm. I also had the clipping scrapbooks which Florence Brookhart Yount lent me for the duration of the project.

The Reader's Guide to Periodical Literature led me to the final source of general information about Brookhart and his period. I read dozens of articles about Brookhart and about agriculture and politics during the 1920 s and early 1930s. And I read some by Brookhart himself, offering his views of a variety of subjects. Many of the articles could be found in the University Libraries and the Interlibrary Loan office provided those the Libraries did not have.

Brookhart served in the Senate during years of great economic growth and great economic collapse. His analysis of the economic situation, especially as it applied to agriculture during the 1920s, held that Wall Street, big business, and the Federal Reserve Board had conspired to depress prices and restrict credit. Not only farmers but all producers, including industrial laborers, were exploited by this system. Brookhart believed that these groups ought to join in a political and economic coalition to protect their own interests. And where they were powerless to protect themselves, the progressive Brookhart said that it was the function of the government to protect them. Long a critic of political and economic abuses 
perpetrated by railroads upon farmers, he advocated government ownership of railroads.

Brookhart believed that the economic system of the $1920 \mathrm{~s}$ and early 1930s, with its emphasis on competition, was a failure, leading only to wars and discord. In its place, he would substitute a cooperative system of banks and marketing organizations, with profits limited and with producers sharing dividends above profits according to the degree of their participation in the cooperative. In this way he thought that farmers and laborers would achieve economic independence and prosperity.

Brookhart always insisted on a market approach to the farm economy. Throughout the 1920s he worked for programs that created domestic and foreign markets for the crops. He carried this campaign for farm markets into the New Deal when in 1933 President Franklin D. Roosevelt appointed him foreign trade advisor for the Agricultural Adjustment Administration. But New Deal agricultural policy went in the direction of production controls and Brookhart resigned from the AAA. Nevertheless, for the remainder of his life he continued his advocacy of market solutions. He tried for the senate one more time with an ill-considered run in 1936. But by then Iowa farmers had turned elsewhere for solutions to their problems. After that he watched from the sidelines. In 1942 he suffered a stroke and his health declined until his death at age 75 in 1944.

He was also critical of the Republican party. Early in the century the party had split into a progressive wing and a regular or "standpat" wing. Part of the progressive critique of the party was that the standpats had been captured by business interests and that reforms were necessary in the party as well as the political and economic systems. Brookhart became a progressive and never abandoned his reforming instincts, even after many other progressives had rejoined the mainstream of the party.

During the 1920s no one dominated Iowa politics like Smith Brookhart. A favorite target of editorial cartoonists, especially the Des Moines Register's Ding Darling, Brookhart was called a 


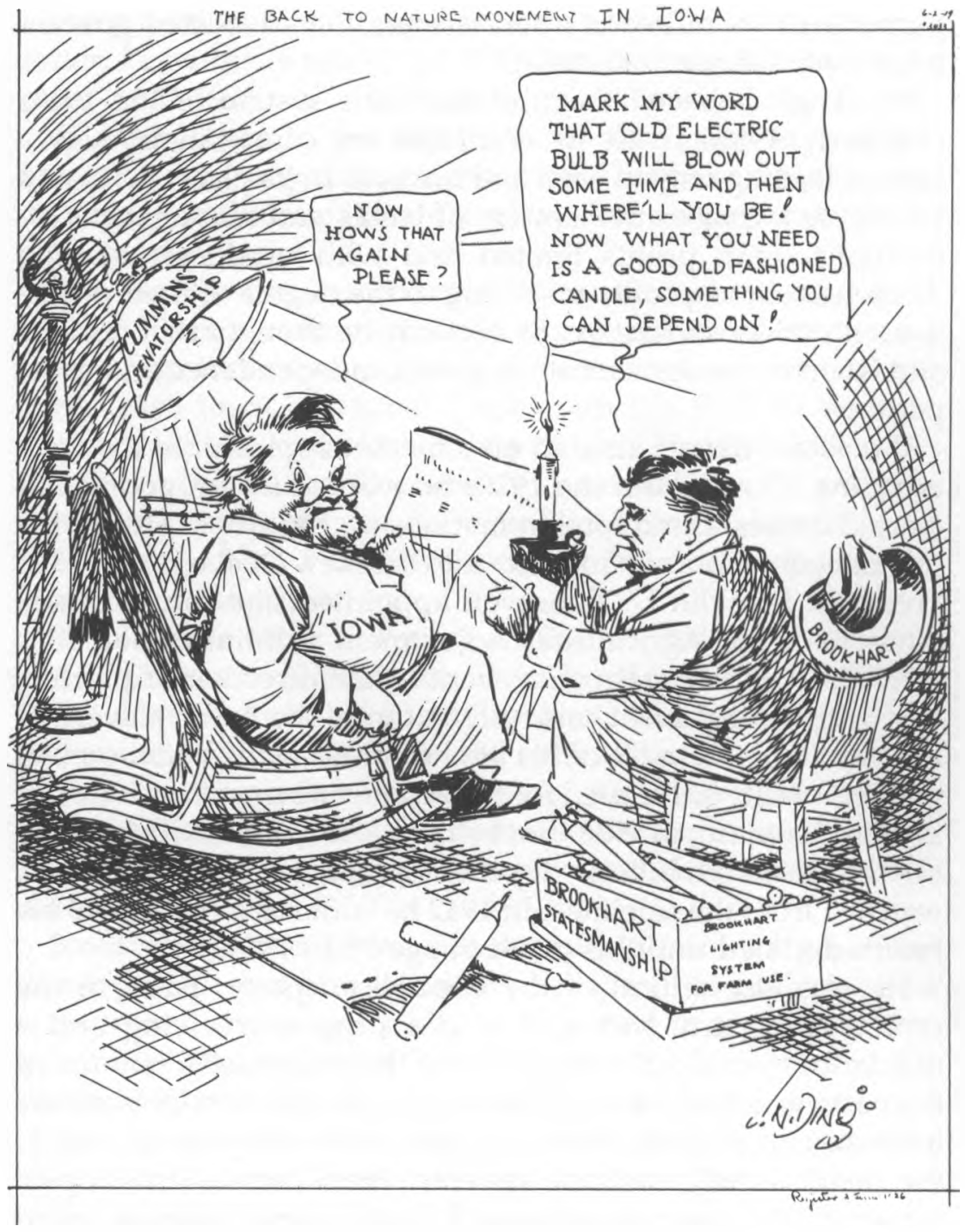


radical, an insurgent, a progressive, a socialist, a communist, a bolshevik, a buffoon, and was numbered among the Senate's "sons of the wild jackass."

With this information as a base, I could now work to fit other pieces into the picture of Smith Brookhart. I knew that an important source of information about his pre-senate years would be home town newspapers. In the years after Brookhart's 1892 arrival in Washington, Iowa, the town had three, and, for a time, four newspapers, all of which now are on microfilm in the Washington Public Library.

Typical of small-town papers, they chronicled the activities of the citizens; not just public activities, business news, and political meetings, but also family events. Slowly a picture began to emerge of the life of the young Brookhart. During these years he began his legal career and started in politics. He married and with his wife began to raise a family that would grow to seven children. He joined the National Guard, and from that grew a lifelong interest in rifle marksmanship.

Newspapers continued to be helpful as I searched for clues about Brookhart's childhood and school years. He was born in Scotland County, Missouri. At one point in his early life the family moved to southern Minnesota, only to return to Missouri after one year. Eventually it moved to Iowa. At age fifteen Brookhart was sent to live with a cousin in Bloomfield so he could attend high school. He remained there to study at Southern Iowa Normal School. The public libraries in Memphis, Missouri, and Bloomfield held the newspapers I needed, and the office of the superintendent of schools in Bloomfield found the graduation program for Brookhart's high school class. The Minnesota Historical Society supplied microfilm copies of the appropriate papers on interlibrary loan.

The newspaper leg of my pilgrimage was made easier by an invaluable tool. In 1979 the State Historical Society of Iowa published A Bibliography of Iowa Newspapers 1836-1976. This is a guide to the extant collections in the state indicating the location of newspapers and whether they are in original format 
or in the form of microfilm. Since 1979 the Society has kept the list up to date as additional papers are discovered.

As I have indicated, newspaper research did not require much travel since most of the papers I needed were close by, or were available on microfilm that could be sent to me. Manuscript collections, however, were a different story. This phase of the research really took me into the "wilderness of the world.'

The manuscript collections I studied included the papers of Iowa political, agricultural, and business leaders. I also consulted the papers of the senators who served with Brookhart, six United States Presidents, and various other national agricultural and labor leaders. At first this wilderness was not too unfriendly since it was in the familiar territory of libraries in Iowa City, Des Moines, and West Branch.

Three leading farm journals were published in Iowa during the period. The papers of the publishers of each are in the University of Iowa Libraries. Edwin T. Meredith published Successful Farming, served as Secretary of Agriculture at the end of the Wilson administration, and was a leading Iowa Democrat. James M. Pierce and later his son, Dante, published the Iowa Homestead, a paper that usually took an anti-establishment view; James Pierce was among Brookhart's first supporters. Henry C. Wallace and later his son, Henry A., edited Wallaces' Farmer; both Wallaces served as Secretary of Agriculture. Taken together, these collections provided a wide range of information about agricultural issues and Iowa politics.

Brookhart's views on the agricultural situation during the 1920s often coincided with those of the Iowa Farmers Union and its leader, Milo Reno. Reno's papers are also in the University Libraries, as are the papers of Brainard Shearer, the publisher of the Iowa Union Farmer.

The papers of several other Iowa political leaders with connections to Brookhart are also in the University Libraries. Most helpful among these were the papers of Clifford Thorne. Thorne and Brookhart had joined forces while still in Washington, Iowa, to represent the interests of farmer groups in 
lawsuits to break up business monopolies. Later, however, Thorne became a political opponent of Brookhart and ran against him in the 1922 primary election.

Brookhart's years of public service coincided with those of Herbert Hoover. I traveled to the Herbert Hoover Presidential Library in West Branch. Hoover had used his position as Secretary of Commerce from 1921 to 1928 to involve himself in most aspects of national life. Once he was in the White House, his positions, especially on agricultural issues, became of even greater interest to Brookhart.

Included in the collections of the Hoover Library are the papers of Iowan Hanford MacNider and his father Charles, a Mason City banker and Iowa business leader. Hanford MacNider was one of the founders of the American Legion and was an early National Commander. In 1924, with financial support from his father, he founded the Republican Service League. Drawing its membership from Iowa Legionnaires, the League served as a political action committee for the American Legion, which by its charter was to be non-partisan. From this base MacNider was the chief organizer of the successful effort to challenge the 1924 election of Brookhart and unseat him from the Senate. It was this collection that gave me the answer to my original question: What happened in 1924?

The other major stops on the Iowa segment of the pilgrimage were the two libraries of the State Historical Society. The manuscript section of the Iowa City branch contained a few helpful collections, but most of my work in the Historical Society was in the Des Moines branch.

At the time I began, I worked in the old Historical Building where conditions were far from ideal. The library was crowded, and the manuscripts were stored in scattered sites throughout the building, including a room referred to as "the vault," which always reminded me of an abandoned elevator shaft. As it turned out, one of the principal collections I needed was stored in "the vault." On one particularly busy day, I was told that, since no employee was available to climb the ladder in the vault to retrieve my material, there would be a considerable delay. I 
offered to climb the ladder myself, but when I discovered that the ladder consisted of two two-by-fours with slats nailed on I changed my mind and decided to wait for professional (and, presumably, insured) assistance.

Sometimes the other patrons proved a problem. On another particularly busy day, I had my typewriter and materials arranged on a table and was hard at work. I left my place briefly to retrieve some papers and returned to find that another patron had pushed my typewriter and materials aside and taken my chair. A librarian successfully mediated the dispute, and I was soon back at work. Over the years new librarians and administrators worked to improve the conditions in the Des Moines facility, and they did a masterful job of making a silk purse out of a sow's ear. The library in the new Historical Building is a fitting reward for those veterans who braved the perils of the old setting.

The papers of a number of prominent Iowans are in the Des Moines library, but the two most important collections for me were those of Albert Baird Cummins and Charles Rawson. A governor and then senator from Iowa, Cummins was a progressive reformer who captured the Iowa Republican Party, and the young Brookhart's imagination, in the early years of the century. In later years, however, Cummins returned to the regular Republican fold, and Brookhart became his opponent. Rawson was the chairman of the Iowa Republican party in the early 1920s; in 1922 he was appointed by the governor to fill out the term of a senator who resigned. Brookhart's first term in the senate followed Rawson's. Together these two collections provided valuable information on the Iowa Republican party's efforts to block Brookhart. The Des Moines library also contained one box of Brookhart materials that had escaped destruction. Most of it, however, was nearly useless ephemera.

It was now time to broaden the scope of my search. I decided to begin with the United States Senate. Brookhart had served in the Senate with 198 people through twelve sessions of Congress. I could not look at the collected papers of all those senators, so I asked myself which ones had served with him in 
all twelve sessions, which in nearly all, and which in only a few sessions. My next questions were: Which of those with whom he served the longest would most likely tell me something about Brookhart? Who, for example, would be allied with him on issues? Who served with him on committees? Whose name was linked with his in newspaper accounts of those years? And finally: Which of these senators had left collected papers which were actually accessible?

In answering this last question, the Historical Office of the United States Senate was a valuable ally. Under the direction of Dr. Richard Baker, the office was then compiling a directory of the locations of the papers of all senators. Dr. Baker provided me with a working copy of a directory which was later published as Guide to Research Collections of Former United States Senators 1789-1982 (1983). After I had eliminated those senators who had little connection with Brookhart and those for whom there are no collected papers, I determined that the papers of ten senators could help. I set off to travel deeper into the wilderness.

During this part of the pilgrimage, I followed in Brookhart's footsteps and traveled from Iowa to Washington, D.C., to work in the Library of Congress. When I made my first trip in 1981, the manuscript room of the Library of Congress was in the Adams Building, a nondescript structure in the block behind the ornate main building which most tourists visit.

Like manuscript rooms everywhere, the Library of Congress's had careful rules governing use of the papers. No pens were allowed, only pencils; no marking on the documents; only one box of documents at a time on the table. The Library also provided note paper or note cards, each page with a hole punched in the corner so that at the end of the day all the pages could be strung on a pencil and shaken to see whether the note-taker was trying to steal a document. The rules of most libraries are reasonable and are a necessary protection for the documents. But the Library of Congress added a touch I did not experience elsewhere: it stationed an armed guard high on a platform overlooking the room. 
When I returned to the Library six years later, the manuscripts room had been moved to the new Madison Building. Same rules, same guard-although the high platform had been eliminated-but a much more pleasant space in which to work. I noticed one other change in six years. During my first visit, my fellow researchers and I used typewriters provided for us in the reading room, usually an old Royal or Remington office model. On my return visit, however, most of the other researchers were using their own personal computers. I had not yet advanced that far into the computer age.

I also used other areas of the Library of Congress. I found newspapers from Florida that told me about the activities of Brookhart's National Guard company, which was stationed there during the Spanish-American War. In the magazine section I located several articles that dealt with Brookhart or the issues in which he had an interest. And I used the ornate main reading room, the one tourists view from a high balcony.

I next wanted to do research in the papers of congressional committees and various executive branch departments so I moved from Capitol Hill down Pennsylvania Avenue to the National Archives. Most tourists enter the Archives to see the Declaration of Independence and the Constitution. Along with those important documents, however, the Archives is filled with millions upon millions of other pieces of paper. And I had to determine precisely which ones I wanted to see.

I knew I wanted to look at papers from the Departments of State, Commerce, War, and Agriculture, as well as several congressional committees. To find them I had to go to the research office for each department. Once I was there, an expert researcher worked with me to identify which papers I wanted and then write an order to bring the papers to the main reading room. Since it was not unusual to wait an hour for the papers to be delivered, I quickly learned to bring along other work to do while I waited. Some of the departments had their own reading rooms in the vicinity of their collections. This was a more convenient arrangement, since the papers could be delivered more quickly. The Archives often seemed like a 
maze, but just at those moments I felt I was lost, someone usually appeared to point me in the right direction.

While in the east I also went to New York to look at the Fiorello La Guardia papers in the New York Public Library. La Guardia was in the House of Representatives while Brookhart was in the Senate, and they worked together on a couple of issues. They also appeared on the lecture platform together, so I thought that perhaps La Guardia's papers could help me. Since my brother lives in Manhattan, I was able to combine a research trip and a weekend with him.

I took a train early one Thursday morning, arrived at Penn Station, and walked up Fifth Avenue in the rain to the New York Public Library, only to discover it was closed on Thursdays. I was used to libraries closing on Mondays, but who ever heard of closing a library in the middle of the week? I returned to the library the next day for what turned out to be one of the most frustrating and fruitless days in all my journeys. The place was dark and dirty, and most of what I wanted was in a warehouse annex eight blocks across town. I have long considered New York City to be the "slough of Despond." Now its great public library became "Doubting Castle, the owner whereof was Giant Despair."

On Monday morning I again boarded a train, this time for a trip up the Hudson River to the Franklin D. Roosevelt Library and Museum at Hyde Park. I had never been up the Hudson and so had looked forward to the opportunity to see the river and West Point. What I actually saw was the inside of very grimy train windows. Moreover, when I arrived at Hyde Park I found that the reading room was being painted, so the employees' lunch room became my reading room. The librarians took the inconvenience in stride, doing a wonderful job of answering my requests and helping my search through the Roosevelt Papers.

Doing manuscript research was hard and tiresome work as I sifted through box after box of documents. Yet the possibility of finding something not seen for decades that could shed light on the subject always gave me the impetus to open that one extra 
folder. One such occasion was a set of letters in the Secretary of Agriculture file at the National Archives.

In 1924 Secretary of Agriculture Henry C. Wallace wrote a number of Iowa bankers to ask their opinion on the continuing farm depression. Most of those who responded blamed the farmers themselves for overextending their credit. Several implied that if they had not spent money on "unnecessary" items like automobiles and telephones, their economic situation would be better. Not all the bankers blamed the farmers, but as a block this set of letters gave me an interesting picture of the views of this important group of lowans.

Another impetus to continue came with my attempts to read the minutes of the Republican conference within the United States Senate. I hoped I could learn about how this group worked and whether Brookhart played a role in its decisionmaking. I was told, however, that only senators could view the minutes and then only in the office of the Secretary of the Republican Conference. I enlisted the aid of Senator Charles Grassley, whose good offices obtained the necessary permission.

The Republican Conference office was on an upper floor of the Capitol Building, down hallways marked "Senators Only." When I arrived, the secretary gave me a desk, a typewriter and hot coffee to keep me going. The minutes did not reveal a great deal, but they did confirm my suspicions about the maverick Brookhart's relationship with other Republican senators. The Senate Historian later told me that I was probably the first outsider to see those minutes!

I suppose all researchers dream of the "big find," the massive collection of letters hidden in an attic that will answer all the questions. No doubt, however, most researchers, like me, learn to settle for "small finds." While I worked at the National Archives, I called on Robert Brookhart, a grandnephew of the senator who was then Assistant to the Archivist. Bob became the source of one small find when he gave me the manuscript of a book the senator worked on in his post-Senate years. Entitled "Cooperative Economics or Illiterate Facts vs. 
Intellectual Fiction," it was a compilation of his ideas on the farm problem and included his plan to create producer cooperatives. There was nothing in the manuscript that I had not read many times elsewhere, but it served as a convenient source for his thoughts.

Still another small find came from Ned Brookhart, a grandson of the senator who worked in the Justice Department. I called on him and told him of my adventures. I also asked if he knew of any family papers, and he assured me that he knew of none. A few days later, however, he called and said, "Guess what I found?" He had gone to his attic and found a set of letters written by the senator's wife, Jennie, to Ned's father and uncles.

Jennie Brookhart was a remarkable woman who kept the family together during the many years the senator was away. Her letters covered the years 1924 through 1944, and they came as close to the "big find" as I would get. Written by a mother for her sons, the letters were filled with family news. She also commented on political events, and she was not hesitant to tell her sons her opinions concerning their father's activities. It was obvious that she usually supported him but not always with great enthusiasm.

My last small find also taught me about the personal Brookhart. During my first visit to Florence Brookhart Yount, she gave me a box of material to sort through. I discovered two sets of notes taken by Florence Brookhart Yount and her sister, Edith, during their father's last illness. From these notes I learned about his grade school days, the childhood games he played, the year in Minnesota, and his first forays into partisan politics. Jennie's letters and the childhood memories added a human dimension to Smith Brookhart, the side the public record could never reveal.

Most people I met on my pilgrimage went out of their way to help me. I can think of only two instances where I met unnecessary human obstacles. The first involved a labor union. The union president was also from Washington County, Iowa, and had supported Brookhart's ideas. At the time it was 
assumed that he also supported him with union funds, and I wanted to find out if that were true. I wrote union headquarters and was assured that if I came I could look at whatever I wanted.

When I arrived, however, a union official gave me photocopies of articles about Brookhart from the union publication (all of which I already had). I asked about the other records to which I had been promised access, and he said I could not see them. My repeated protests about previous arrangements and two days travel were to no avail.

The second occasion involved a national organization of which Brookhart was a long-time director and president. Once again I had written letters in advance to make all the proper arrangements. But when I arrived at the headquarters the librarian had decided that I could not enter the library. One member of the staff agreed to get what I wanted, and he even set up a card table in his office for me to use. Since I was not sure what the library contained, I had to describe my needs and hope that my helper could find what I wanted. He was very gracious and did what he could for me, but it was hardly a convenient arrangement. I also wanted to see membership records and the minutes of board meetings to determine the extent of Brookhart's involvement with this group. I had hoped to discover whether he played an active role in policy setting within the board. Following repeated calls to the headquarters, I was told, "We have what you want to see but it has been decided that you cannot see it."

Most of the time people were eager to help. I wrote dozens of letters to people who knew Brookhart or knew about him. Some were able to help, and others were not, but almost without fail they responded promptly and wished me well. Still other people were willing to be interviewed and generously shared their time and memories.

I simply could not have done the job without the assistance of librarians. Their tenacity in searching out arcane facts often exceeded my own. On a number of occasions when I was ready to give up on an item I would hear, "let's try one more place," 
and often that proved to be just the right place to look. When I was unable to travel to a distant library for the information source it contained, I wrote the librarian for the information and almost always received a prompt reply that saved me countless miles of travel.

When I did need to travel a great distance, I received grants from the Herbert Hoover Presidential Library's Hoover Scholars program. This money took me to Columbus, Ohio, to look at the President Warren G. Harding papers; to Columbia, Missouri, to research several collections at the University of Missouri; and to Helena, Montana, to view the Senator Burton Wheeler papers. St. Ambrose University, where I teach, gave me a faculty development grant to buy a microfilm reader for my office and its library has obtained newspapers for me through interlibrary loan.

My pilgrimage is now coming to an end. The book still needs some revising, but I hope to have it published soon. I am aware that I will never know everything about Smith Brookhart, but I feel comfortable that I have come as close as anyone ever will. There were a few times in the Slough of Despond, but for the most part the journey was exciting and fruitful. I can say with Bunyan's Mr. Valiant-for Truth that:

though with great difficulty I am got hither, yet now I do not repent me of all the trouble I have been at to arrive where I am. 
http://ir.uiowa.edu/bai/vol52/iss1 